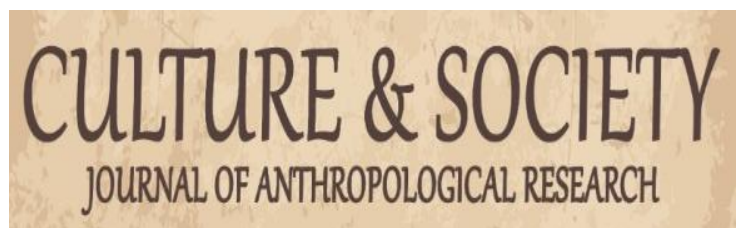

Culture \& Society: Journal of Anthropological Research

VOL. 1 NO. 1 SEPTEMBER 2019

http://culture.ppj.unp.ac.id

Email: culture@ppj.unp.ac.id

ISSN: 2686-343X (E-ISSN) 2686-3421 (P-ISSN)

DOI: https://doi.org/10.24036/culture/vol1-iss1/4

\title{
Adaptasi Masyarakat Kawasan Banjir Gang Rawa Bangun Kelurahan Bangkinang Kecamatan Bangkinang Kota Kabupaten Kampar
}

\author{
Yelvika Angraini ${ }^{1}$, Ikhwan Ikhwan ${ }^{2}$ \\ ${ }^{1,2}$ Universitas Negeri Padang \\ Email: angraini.27vika@gmail.com, $\underline{\text { ichone.in@gmail.com }}$
}

\begin{abstract}
Abstrak
Penelitian ini bertujuan untuk mendeskripsikan adaptasi sosial masyarakat kawasan banjir di Gang Rawa Bangun, Kelurahan Langgini, Bangkinang Kota, Kabupaten Kampar, Kota Bangkinang, Riau. Penelitian ini dianalisis menggunakan teori motif yang bertujuan (in order to motive). Metode yang digunakan ialah pendekatan kualitatif dengan tipe studi kasus instrumental, dan menggunakan teknik Purposive Sampling dalam pemilihan informan. Teknik pengumpulan data yang digunakan ialah analisis data menurut Miles dan Huberman yang meliputi observasi, wawancara, dan studi dokumentasi. Hasil penelitian ini menunjukan adaptasi yang dilakukan masyarakat kawasan banjir adalah masyarakat mulai menyesuaikan diri dengan lingkungan sosialnya dan melakukan usaha dalam perubahan kondisi lingkungan sekitarnya, demi untuk bertahan hidup di kawasan tersebut. Alasan masyarakat tidak ingin pindah dan melakukan adaptasi ialah karena sudah nyaman dengan lingkungan sekitarnya, solidaritas yang erat antar masyarakat, serta adanya harapan yang diberikan pemerintah kepada masyarakat setempat untuk menanggulangi banjir pada kawasan tersebut. Sehingga hal tersebut yang melatarbelakangi adaptasi mereka selama bertahan tinggal di kawasan banjir. Adaptasi yang dilakukan dapat berupa perubahan fisik dan perubahan sosial.
\end{abstract}

Kata Kunci: Adaptasi Sosial, Masyarakat, Banjir

\section{Abstract}

This study aims to describe the social adaptation of flooded communities in Gang Rawa Bangun, Langgini Village, Bangkinang Kota, Kampar District, Bangkinang City, Riau. This study was analyzed using the aim motive theory (in order to motive). The method used is a qualitative approach to the type of instrumental case study, and using purposive sampling techniques in the selection of informants. Data collection techniques used were data analysis according to Miles and Huberman which included observations, interviews, and documentation studies. The results of this study indicate that the adaptation carried out by the flood zone community is that the community begins to adjust to their social environment and make efforts to change the surrounding environmental conditions, in order to survive in the region. The reason people do not want to move and adapt is because they are comfortable with the surrounding environment, close solidarity between communities, and the hope given by the government to local communities to cope with flooding in the region. So that this is the background of their adaptation while surviving in flood areas. Adaptation can be in the form of physical and social changes.

Keywords: Social Adaptation, Society, Flooding

Received: August 29, $2019 \quad$ Revised: September 4, 2019 Published: September 6, 2019

Culture \& Society: Journal of Anthropological Research Vol. 1, No. 1, Th. 2019

2686-343X (E-ISSN) 2686-3421 (P-ISSN) 


\section{Pendahuluan}

Bencana adalah ancaman besar bagi manusia yang dapat menurunkan ketahanan wilayah(Asrofi, Hardoyo, \& Sri Hadmoko, 2017). Bencana alam merupakan bencana yang terjadi karena faktor alam atau akibat ulah manusia(Habiba, Nurdin, \& Muhamadd, 2017). Salah satu bencana alam yang sering terjadi di Indonesia adalah banjir. Penyebab terjadinya banjir yaitu curah hujan yang tinggi, yang mengakibatkan tidak tertampungnya air oleh saluran drainase, atau karena adanya penyumbatan aliran air, sehingga air meluap(Kurnia Shalihat, 2014). Curah hujan merupakan jumlah air yang turun pada suatu tempat yang datar dalam waktu tertentu dengan asumsi tidak mengalir, dan tidak meresap(Mulyono, 2014).

Curah hujan di Bangkinang Kota terbilang cukup tinggi. Intensitas curah hujan ialah jumlah curah hujan yang jatuh yang menandakan lebat atau tidak. Intensitas yang tinggi berarti bahwa air hujan yang turun dalam jumlah yang banyak dalam waktu singkat(Arif Ismul Hadi, Suwarsono, \& Herliana, 2017). Banjir dapat terjadi pada daerah dataran rendah, daerah datar, dan daerah dekat dengan sungai. Keberadaan sungai pada suatu daerah tidaklah memiliki fungsi yang sama. Pada sebagian orang, sungai dapat dijadikan sebagai sebuah sumber kehidupan. Namun bagi sebagian lagi sungai dapat menjadi sumber bencana, yang menyebabkan merugikan masyarakat(Josia O. Lempoy, Waani, \& Warouw, 2017).

Oleh karena itu, masyarakat perlu mengetahui mengenai mitigasi bencana, sebagai berikut(Jati, 2013).

a. Sebelum Banjir

Ketika keadaan tidak terjadi bencana, masyarakat merencanakan penanggulangan, mengurangi resiko banjir, pencegahan, dan sebagainya. Sedangkan saat keadaan berpotensi banjir, masyarakat mulai siap siaga akan datangnya banjir, memberikan peringatan dini kepada masyarakat lainnya, dan melakukan pegungsian, serta meletakkan barang-barang ke tempat yang lebih tinggi.

b. Saat Banjir

Ketika bencana terjadi, masyarakat melakukan penilaian pada tempat kejadian, kerusakan, kerugian, dan sumber daya. Masyarakat mulai mencari dan menentukan status keadaan darurat. Kemudian, jika diperlukan, dilakukan penyelamatan terhadap masyarakat, serta memulihkan sarana dan prasarana.

c. Setelah Banjir

Sesudah terjadi banjir, korban dan pengungsi (jika ada pengungsi) kembali ke rumah mereka masing-masing, melalui kegiatan rehabilitasi ialah kegiatan untuk mengembalikan keadaan tempat yang terkena banjir ke keadaan yang lebih baik, agar mereka dapat beraktifitas seperti biasanya.

Permasalahan banjir di lingkungan masyarakat mau tidak mau harus dihadapi, maka masyarakat tersebut cenderung beradaptasi dan berusaha untuk mengurangi dampak permasalahan lingkungan. Salah satu contohnya adalah adaptasi sosial yang dilakukan oleh masyarakat di Gg Rawa Bangun. Adaptasi sosial merupakan cara seseorang dalam bertahan hidup dengan lingkungan sekitar(Indryanto, 2016). Adaptasi akan berjalan dengan baik jika masyarakat dapat beradaptasi dengan lingkungannya sehingga dapat berbaur dengan kelompk masyarakat lainnya (Wende, Erianjoni, \& Nora, 2018). Meskipun begitu, adaptasi sosial terjadi atas beberapa syarat dasar untuk tetap bertahan hidup, salah satunya ialah dapat menyesuaikan diri terhadap keadaan yang berubah(Tamba \& Manurung, 2015). Proses adaptasi sosial dilihat pada kemampuan masyarakat dalam mengatasi kecemasan terhadap masalah yang dihadapinya, serta kemampuan berhubungan dengan orang lain demi menciptakan hubungan sosial(Nuziar, 1987). Adaptasi dapat berupa dari individu, kelompok perubahan, atau keadaan yang diciptakan(Winata, 2014). Penyesuaian diri dengan lingkungan fisik dikenal dengan istilah adaptasi, dan penyesuaian diri dengan lingkungan sosial dikenal adjustment.

\section{Culture \& Society: Journal of Anthropological Research Vol. 1, No. 1, Th. 2019}


Gang Rawa Bangun merupakan salah satu kawasan yang berada di Kelurahan Langgini, Kecamatan Bangkinang Kota, Kabupaten Kampar, Kota Bangkinang, Riau. Pada kawasan ini, banjir yang terjadi bukan karena luapan air sungai, melainkan dari luapan air parit yang mempunyai lebar sekitar 2 meter dengan kedalaman sekitar 1,5 meter. Aliran air parit tersebut dialirkan ke sungai Kampar. Kawasan Rawa Bangun merupakan salah satu kawasan di Kabupaten Kampar yang setiap tahunnya terkena banjir, baik itu banjir dalam skala besar maupun dalam skala kecil.

Ketika musim hujan tiba, masyarakat setempat cenderung merasa khawatir akan tibanya banjir, apalagi hujan yang turun agak lebat yang mengakibatkan meluapnya air parit. Hasil observasi lainnya yang ditemukan oleh peneliti ialah semua rumah masyarakat yang terendam banjir akan menyisakam lumpur dan tanah kuning, serta sampah-sampah pun ikut terbawa ke dalam rumah masyarakat. Jika ada warga yang memerlukan bantuan, seperti mengangkat pagar besi yang terlepas karena hantaman air banjir, maka warga yang lain pun akan ikut membantu.

Dari hasil wawancara dengan beberapa warga di Gg Rawa Bangun, ditemukan bahwa banjir yang melanda kawasan ini sudah ada sejak tahun 1995. Namun, ketika itu banjir yang terjadi hanya sekali setahun. Sebelumnya, di kawasan tersebut hampir tidak pernah terjadi banjir, banjir yang terjadi pun mungkin hanya terjadi sekali dalam 2 atau 3 tahun. Pada tahun 2002, kawasan ini terendam banjir lebih dari sekali. Hal ini dikarenakan akses aliran air parit di beberapa tempat ditutup dengan adanya bangunan ruko diatasnya. Sehingga aliran air yang tak bisa mengalir dengan baik maka akan teralir deras di kawasan ini.

Selain itu, peneliti juga menemukan bahwa terhitung dari 3 tahun yang lalu sudah terjadi banjir lebih kurang sebanyak 20 kali lebih. Pada tahun 2018 sudah terjadi banjir lebih kurang sebanyak 10 kali yang merendam beberapa rumah warga. Hingga saat ini, banjir terparah dan terdalam sepanjang tahun terjadi pada hari Rabu, 28 November 2018. Pada banjir ini, menyebabkan semua rumah yang ada di Gg. Rawa Bangun terendam banjir tanpa terkecuali. Bahkan sekolah agama (MDA) dan mushalla pun terkena banjir. Air banjir yang merendam rumah-rumah bukan hanya melewati pintu. Melainkan air banjir tersebut masuk dari jendela rumah warga. Bahkan, pagar besi yang biasanya digunakan untuk menghalang air banjir masuk ke dalam rumah pun amblas akibat derasnya volume air banjir.

Kemudian, dalam bencana banjir ini juga mengakibatkan masyarakat setempat mengalami kerugian, seperti alat-alat elektronik yang konslet akibat terendam banjir yang berupa kulkas dan mesin cuci, alat-alat rumah tangga lainnya seperti lemari pakaian, lemari buku, lemari alat-alat masak, tempat tidur, kursi dan meja. Bahkan kolam-kolam ikan milik warga pun ikut meluap dan semua ikan-ikannya terbawa banjir. Sehingga, ketika air banjir surut, semua kolam ikan warga tidak berisi ikan lagi.

Meskipun banjir terus menerus terjadi pada kawasan ini, masyarakat Rawa Bangun seakan sudah terbiasa dengan bencana tersebut dan memiliki alasannya tersendiri, sehingga mereka tetap tinggal dan beradaptasi dengan kondisi yang ada. Terlebih saat ini hujan selalu saja mengguyur Kota Bangkinang pada malam hari.

Alasan masyarakat tidak mau pindah dari kawasan ini adalah karena sudah terciptanya rasa nyaman dengan lingkungan sosial disekitarnya. Ada rasa solidaritas antar masyarakat yang sangat erat. Apalagi beberapa masyarakat sudah sejak lama tinggal di daerah ini. Mereka mempunyai historis masing-masing di rumah mereka, seperti anak/cucu mereka yang lahir di rumah tersebut, merayakan pesta pernikahan, merayakan pesta ulang tahun, dan lain sebagainya.

Selain itu, masyarakat tetap bertahan tinggal di kawasan banjir ini adalah diberinya harapan oleh pemerintah kepada masyarakat dalam menanggulangi banjir di kawasan ini. Sehingga masyarakat pun senantiasa berharap akan datangnya bantuan berupa penanggulangan banjir di kawasan ini. Namun, sejak beberapa kali pihak pemerintah datang ke kawasan ini, baru-baru ini dibuat penambahan tinggi di bibir parit. Penambahan tinggi di bibir parit tersebut tidak di buat dengan baik. Sehingga sekarang pun sudah rusak dan patah, dan memudahkan air parit meluap dengan cepat.

\section{Culture \& Society: Journal of Anthropological Research Vol. 1, No. 1, Th. 2019}




\section{Metode Penelitian}

Dalam penelitian ini, peneliti menggunakan penelitian kualitatif, yang berfokus pada fenomena sosial, dengan tipe studi kasus, yang berusaha menemukan makna, menyelidiki proses, dan memperoleh pengertian serta pemahaman mendalam dari individu, kelompok, atau situasi(Emzir, 2012). Dalam penelitian ini, peneliti menggunakan tipe studi kasus instrumental, digunakan untuk memahami atau menekankan pada pemahaman tentang suatu isu atau merumuskan kembali suatu penjelasan secara teoritis(Yusuf, 2016).

Pemilihan informan dilakukan dengan teknik Purposive Sampling, yaitu teknik pengambilan sampel sumber data dengan pertimbangan tertentu, yang dilakukan dengan sengaja sesuai dengan tujuan penelitian(Sugiyono, 2017). Kriteria informan yaitu orang-orang yang dianggap paling tahu dan ditentukan berdasarkan asumsi peneliti bahwa informan tersebut dapat memberikan data sesuai tujuan penelitian. Maka, informan penelitian ini adalah warga yang tinggal di Gg Rawa Bangun sekitar lebih kurang 10 tahun atau lebih, dengan kriteria masyarakat yang rumahnya paling rendah, masyarakat yang rumahnya dengan ketinggian standar, dan msyarakat yang rumahnya paling tinggi.

Teknik selanjutnya yaitu melaksanakan observasi. Tipe observasi yang digunakan adalah observasi partisipan, di mana peneliti ikut terlibat pada permasalahan penelitian(Emzir, 2012). Dalam observasi ini, peneliti tinggal dan ikut terlibat dalam aktivitas masyarakat. Selanjutnya, dilakukan teknik wawancara, yang terdiri atas sejumlah pertanyaan yang dipersiapkan oleh peneliti dan diajukan kepada informan terkait permasalahan penelitian dan peneliti merekam jawaban-jawabannya sendiri(Emzir, 2012).

Selain itu, peneliti menggunakan studi dokumentasi berupa foto-foto terkait banjir yang melanda kawasan tersebut(Emzir, 2012). Selain itu, pada penelitian ini peneliti mengumpulkan data dari sumber-sumber berupa jurnal, skripsi, artikel, buku, serta data tertulis berupa data Kecamatan Bangkinang Kota.

\section{Hasil dan Pembahasan}

Pada hakikatnya, manusia adalah makhluk individu dan makhluk sosial. Sebagai makhluk individu, manusia memiliki sifat dan sikap yang berbeda dalam bertindak. Sebagai makhluk sosial, manusia cenderung tidak bisa hidup tanpa bantuan orang lain, dalam setiap kegiatan akan membutuhkan orang lain. Dalam menghadapi bencana sekalipun, manusia akan menjadi makhluk individu dan makhluk sosial.

Banjir merupakan salah satu bencana yang sangat meresahkan masyarakat yang terkena dampaknya. Banjir di Gg. Rawa Bangun sudah terjadi sejak tahun 90-an. Banjir yang terjadi di Gg. Rawa Bangun terjadi karena hujan deras yang turun dalam waktu yang cukup lama. Parit tersebut menjadi pusat perkumpulan air dari aliran yang sebelumnya, yang menyebabkan air hujan tersebut tidak dapat ditampung lagi oleh parit tersebut, sehingga air parit meluap. Dalam tahun 2019 sudah terhitung sebanyak 8 kali terjadi banjir di Gang tersebut. Penyebab terjadinya banjir di kawasan tersebut ialah kurangnya kesadaran masyarakat dalam membuang sampah. Terutama kurangnya kesadaran masyarakat dalam membuat bangunan, baik itu bangunan rumah maupun toko-toko.

Gang Rawa Bangun merupakan salah satu kawasan langganan banjir setiap tahunnya. Hubungan manusia dengan lingkungan dapat ditunjukkan bahwa seluruh aspek sosial dan budaya dapat patuh dan tunduk terhadap lingkunan. Hal tersebut dapat terlihat pada masyarakat Gg. Rawa Bangun dalam menghadapi banjir. Masyarakat di Gg. Rawa Bangun sudah dapat mengetahui mengenai informasi akan datangnya banjir melalui pengalaman yang mereka alami. Dengan begitu mereka dapat mengidentifikasi sendiri mengenai banjir yang akan datang dan tindakan apa yang harus mereka lakukan ketika banjir tiba. Meskipun begitu, masyarakat tetap mau bertahan menetap di kawasan tersebut. 
Sebagaimana yang dijelaskan oleh Alfred Schutz dalam teori motif yang bertujuan (in order to motive) (Guntaradewa, 2011). Teori ini terlihat pada tujuan, alasan, dan bagaimana adaptasi yang dilakukan oleh masyarakat untuk menghadapi banjir. Dalam penelitian ini, tujuan masyarakat dalam beradaptasi yaitu untuk tetap bertahan di kawasan tersebut. Alasan masyarakat tetap bertahan tinggal di kawasan tersebut ialah karena sudah nyaman dengan lingkungan sekitar, selain itu letak kawasan ini pun sangat strategis yaitu di tengah kota. Selain itu, alasan masyarakat tidak mau pindah adalah karena interaksi antar masyarakat sudah terjalin sangat erat, sehingga menciptakan rasa solidaritas dan rasa kekeluargaan di antara mereka, dan saling menjaga tali silaturrahim satu sama lain guna untuk mencegah terjadinya konflik antar masyarakat. Adaptasi yang dilakukan masyarakat bertujuan untuk tetap bertahan hidup di lingkungan yang diinginkannya. Adaptasi dapat terjadi karena adanya interaksi antara masyarakat satu dengan masyarakat lainnya, guna untuk menciptakan keharmonisan dalam menjalin suatu hubungan kekeluargaan. Meskipun berbeda suku bangsa, masyarakat akan tetap harmonis dengan adanya rasa toleransi dan solidaritas. Rasa solidaritas dapat terwujud dengan baik ketika masyarakat saling bantu membantu satu sama lainnya. Dengan adanya rasa toleransi dan solidaritas, maka akan menciptakan rasa nyaman. Sehingga masyarakat pun tidak mau untuk berpindah tempat ke tempat lainnya, meskipun di kawasan tersebut dilanda banjir.

Agar tercipta solidaritas yang lebih baik dalam masyarakat, maka diperlukan komunikasi yang baik. Komunikasi yang dilakukan dapat berupa bertegur sapa. Bertegur sapa bisa dilakukan dimana saja, baik itu di depan rumah, pasar, di masjid, dan di tempat lainnya. Bagi masyarakat yang belum kenal satu sama lain, bertegur sapa dapat dijadikan sebagai penyatu agar lebih saling mengenal. Bagi masyarakat yang sudah saling mengenal, bertegur sapa dilakukan untuk mempererat tali silaturrahim antar masyarakat. Selain itu, kerja sama dan gotong royong juga diperlukan untuk mempererat rasa solidaritas serta dapat menciptakan rasa nyaman dengan lingkungan sekitar.

Dalam teori motif yang bertujuan (in order to motive) yang dikemukakan oleh Schutz, dijelaskan bahwa untuk mencapai keinginannya, aktor akan melakukan beberapa tindakan sesuai yang diharapkan untuk masa depannya(Guntaradewa, 2011). Dalam penelitian ini, masyarakat sebagai aktor melakukan bentuk tindakan adaptasi yang bertujuan untuk tetap bertahan di kawasan tersebut. Adaptasi yang dimaksud adalah adaptasi sosial yang dilakukan masyarakat di Gg. Rawa Bangun, dalam melakukan interaksi dapat menciptakan toleransi dan solidaritas antar masyarakat dalam kehidupan sehari-hari. Masyarakat yang rumahnya paling rendah, masyarakat yang rumahnya dengan ketinggian standar, dan masyarakat yang rumahnya paling tinggi, melakukan kegiatan adaptasi sosial yang sama. Adaptasi sosial yang dilakukan dapat terjadi dengan adanya hubungan kerja sama yang baik serta komunikasi yang baik pula. Hal tersebut dapat terlihat ketika sebelum terjadi banjir, saat banjir terjadi, dan sesudah banjir terjadi.

\section{Sebelum Terjadi Banjir}

Adaptasi yang dilakukan masyarakat sebelum datangnya banjir adalah dengan memasang pagar besi di halaman rumah dan besi penghambat air di depan pintu. Pemasangan tersebut dilakukan bertujuan untuk menghambat air banjir masuk ke dalam rumah. Meskipun terkadang air banjir dapat melompati pagar besi tersebut, namun masyarakat tetap melakukannya untuk mengurangi resiko masuknya air banjir secara tiba-tiba ke dalam rumah. Kemudian masyarakat juga memberikan selotip di jendela-jendela rumahnya, untuk mengurangi resiko air banjir masuk melalui jendela. Kemudian memindahkan barang-barang ke tempat yang lebih tinggi agar tidak terkena banjir, seperti memindahkan kendaraan, kasur, dan barang-barang elektronik dan rumah tangga lainnya. 


\section{Saat Terjadi Banjir}

Ketika air parit sudah mulai meluap, adaptasi yang dilakukan masyarakat ialah tetap tinggal di dalam rumah. Antar masyarakat memberikan kode kepada masyarakat lainnya, yang menandakan bahwa air parit sudah meluap. Kode tersebut dapat berupa sinar lampu senter yang dilambaikan kepada masyarakat disekitarnya. Saling memberikan informasi kepada tetangga sekitar itu sangatlah penting demi keselamatan bersama. Sebagian masyarakat memilih untuk pindah atau mengungsi ke lantai dua rumahnya, dan sebagian lagi mencari tempat yang lebih tinggi dan tidak terkena banjir, seperti di atas bangku, meja, dan lainnya. Masyarakat selalu siaga dan berjaga di rumah agar perabot atau alat-alat yang ada dirumahnya agar tidak hilang ataupun terbawa arus banjir. Bagi masyarakat yang mempunyai kolam ikan, mereka cenderung berjaga agar ikannya tidak terlepas atau keluar dari kolam. Kerja sama antar masyarakat akan semakin terjalin ketika masyarakat yang satu membantu masyarakat lainnya yang membutuhkan pertolongan. Mereka saling membantu mengambil batang kayu dan sampah-sampah yang dapat menghalangi aliran air banjir.

\section{Sesudah Terjadi Banjir}

Setelah banjir mulai surut, adaptasi yang dilakukan masyarakat adalah menimba air yang terkurung di dalam rumah dengan menggunakan gayung atau ember kecil melewati jendela atau pintu. Setelah surut, pagar besi di depan pintu mulai di buka dan masyarakat membersihkan rumah mereka masing-masing, seperti membersihkan lumpur, sisa genangan air, dan merapikan barang-barang ketempat semula. Kemudian, sebagian masyarakat menjemur beberapa alat-alat rumah tangga yang terendam banjir, seperti menjemur kasur, karpet, pakaian, dan sebagainya. Setelah beberapa rumah warga bersih, barulah sebagian mereka mendatangi salah satu rumah tetangga yang memerlukan bantuan dikarenakan letak rumah tersebut terletak didataran lebih rendah. Sebagian warga lagi bergotong royong untuk membersihkan sisa banjir seperti puing-puing kayu dan sampah plastik.

Seperti yang dijelaskan Schutz, dari adaptasi yang dijelaskan di atas, masyarakat akan melakukan beberapa tindakan yang merujuk pada masa depan (Guntaradewa, 2011). Hal ini terlihat pada tindakan masyarakat untuk mengatasi dan mengantisipasi banjir yang akan terjadi selanjutnya. Masyarakat mulai membangun rumah menjadi dua lantai. Ada juga masyarakat yang membuat pagar sekeliling rumahnya, serta membuat dan menata semua tanamannya di halaman rumahnya sedemikian rupa, yang bertujuan untuk menghambat laju air banjir masuk ke dalam rumahnya secara langsung. Selain itu, sebagian masyarakat ada meninggikan rumahnya dengan cara menimbun kembali teras dan halaman rumahnya dan membuat penghambat atau tanggul agar air banjir tidak masuk ke dalam rumahnya. Berikut beberapa gambar mengenai tindakan adaptasi yang dilakukan masyarakat terhadap pencegahan masuknya air banjir. Meskipun sering terkena banjir, namun bantuan yang khusus dari pemerintah untuk masyarakat tersebut tidak ada. Bantuan tersebut akan diberikan ketika ada masyarakat yang melapor ke kelurahan atau camat. Namun dari masyarakat sendiri tidak ada melapor terkait banjir yang terjadi, yang dikarenakan banjir tersebut sering terjadi pada malam hari. Meskipun demikian, pemerintah juga berupaya akan menanggulangi banjir di kawasan tersebut, dengan akan dibuatnya peralihan drainase, agar air hujan yang turun tidak berkumpul lagi di kawasan tersebut. Dengan adanya harapan yang diberikan oleh pemerintah terhadap masyarakat untuk menanggulangi banjir, membuat masyarakat tetap bertahan tinggal di kawasan tersebut dengan harapan banjir tersebut dapat ditanggulangi.

\section{Kesimpulan}

Adaptasi masyarakat yang rumahnya paling rendah, masyarakat yang rumahnya dengan ketinggian standar, dan masyarakat yang rumahnya paling tinggi, melakukan kegiatan adaptasi sosial yang sama. Adaptasi sosial yang dilakukan dapat terjadi dengan adanya hubungan kerja 
sama yang baik serta komunikasi yang baik pula. Dalam melakukan adaptasi, dilatarbelakangi oleh beberapa alasan yang menyebabkan masyarakat tetap bertahan di kawasan tersebut. Alasannya adalah masyarakat sudah merasa nyaman dan aman, dan sudah terjalin rasa solidaritas antar masyarakat, serta alasan lainnya. Karena beberapa alasan tersebut yang menyebabkan masyarakat melakukan adaptasi untuk tetap tinggal di Gg. Rawa Bangun. Adaptasi yang dilakukan oleh masyarakat Gg. Rawa Bangun dapat melalui interaksi antar masyarakat yang dapat menciptakan toleransi dan solidaritas. Solidaritas yang sudah terjalin antar masyarakat akan membuat rasa nyaman di lingkungan sekitarnya. Sehingga terjaga tali silaturrahim antar masyarakat, sebagai bentuk terhindarnya dari konflik. Dalam menghadapi banjir, masyarakat tidak hanya diam. Masyarakat mulai menyesuaikan diri dengan lingkungan sosialnya dan melakukan usaha dalam perubahan kondisi lingkungan sekitarnya.

\section{Daftar Pustaka}

Arif Ismul Hadi, Suwarsono, \& Herliana. (2017). Analisis Karakteristik Intensitas Curah Hujan di Kota Bengkulu. Jurnal Fisika Flux, 7(2), 119-129. Retrieved from Repository.unib.ac.id

Asrofi, A., Hardoyo, S. R., \& Sri Hadmoko, D. (2017). Strategi Adaptasi Masyarakat Pesisir Dalam Penanganan Bencana Banjir Rob Dan Implikasinya Terhadap Ketahanan Wilayah (Studi Di Desa Bedono Kecamatan Sayung Kabupaten Demak Jawa Tengah). Jurnal Ketahanan Nasional, 23(2), 1. https://doi.org/10.22146/jkn.26257

Emzir. (2012). Metodologi Penelitian Kualitatif Analisis Data. Jakarta: Rajawali Pers.

Guntaradewa, O. Y. (2011). Motif Tindakan Mahasiswa dalam Gerakan Mahasiswa Mengajar. 89. Retrieved from http://journal.unair.ac.id/download-fullpapers-kmntse4bb8fc1d6full.pdf

Habiba, N., Nurdin, M. F., \& Muhamadd, R. . T. (2017). Adaptasi Sosial Masyarakat Kawasan Banjir di Desa Bojonghoa Kecamatan Rancaekek. 1(March), 143-151. Retrieved from Jurnal.unpad.ac.id

Indryanto, R. (2016). Adaptasi sosial etnis jawa pada masyarakat di kelurahan sumpang binangae, kecamatan barru, kabupaten barru. Retrieved from Eprints.unm.ac.id

Jati, T. D. K. (2013). Kesiapsiagaan Masyarakat Terhadap Bencana Banjir di Kelurahan Jagalan Kecamatan Jebres Kota Surakarta. 1-110. Retrieved from Eprints.ums.ac.id

Josia O. Lempoy, Waani, J. O., \& Warouw, F. (2017). Adaptasi Permukiman Sungai di Kampung Tubir Kota Manado Terhadap Resiko Banjir. Jurnal Arsitektur DASENG UNSRAT Manado, 6(1). Retrieved from http://ejournal.unsrat.ac.id

Kurnia Shalihat, A. (2014). Pola Adaptasi Masyarakat Terhadap Banjir di Perumahan Genuk Indah Kota Semarang. 1-74. Retrieved from https://lib.unnes.ac.id/21284/1/3211410026-s.pdf

Mulyono, D. (2014). Analisis karakteristik curah hujan di wilayah Kabupaten Garut Selatan. Jurnal Konstruksi, 13(1), 1-9. Retrieved from https://jurnal.sttgarut.ac.id

Nuziar, D. (1987). Adaptasi Sosial Mahasiswa Ilmu Informasi dan Perpustakaan di Lingkungan Kampus-Fisip Universitas Airlangga. Kendall's Advanced Theory of Statistics, 5(1), 291-319. Retrieved from Journal.unair.ac.id

Sugiyono. (2017). Metode Penelitian Kuantitatif, Kualitatif, dan R\&D. Bandung: Alfabeta.

Tamba, P., \& Manurung, R. (2015). Adaptasi Masyarakat Dalam Merespon Perubahan Fungsi Hutan. 3(1), 150-164. Retrieved from Jurnal.usu.ac.id

Wende, F., Erianjoni, E., \& Nora, D. (2018). Strategi Adaptasi Mahasiswa UNP Non Muslim Dalam Kegiatan Praktek Kependidikan (PLK) Pada Sekolah Praktek Lapangan Di Kota Padang. Jurnal Perspektif, 1(4), 11-16. Retrieved from http://perspektif.ppj.unp.ac.id/index.php/perspektif/article/view/56

Winata, A. (2014). Adaptasi Sosial Mahasiswa Rantau Dalam Mencapai Prestasi Akademik. 50. Retrieved from http://repository.unib.ac.id/9181/

Yusuf, M. (2016). Metode Penelitian Kuantitatif, Kualitatif \& Penelitian Gabungan. Jakarta: Kencana.

\section{Culture \& Society: Journal of Anthropological Research Vol. 1, No. 1, Th. 2019}

